\title{
Evaluation of Sustainable Impacts on Wastewater Treatment of Tofu Industry
}

\author{
L. A. Wardani ${ }^{1}$, S. W. Utomo ${ }^{2}$, H. Kusnoputranto ${ }^{3}$ \\ \{larasandria90@gmail.com ${ }^{1}$, suyudwarno@gmail.com ${ }^{2}$, haryoto_k@yahoo.com ${ }^{3}$ \} \\ School of Environment, University of Indonesia ${ }^{1}$, School of Environment and Department of \\ Environmental Health - Faculty of Public Health, University of Indonesia ${ }^{2}$, School of Environment \\ and Department of Environmental Health - Faculty of Public Health, University of Indonesia ${ }^{3}$
}

\begin{abstract}
Currently, tofu wastewaters from CV. Proma has been treated using anaerobic technology up-flow Fixed Bed reactor. The aim of the research is to evaluate three impacts (environmental, social, and economic) of sustainability on wastewater treatment at CV. Proma tofu industry. This research method was conducted using direct observation in the field and interviewing to community. The evaluation environmental results show that technology can be reducing organic materials in wastewater up to $83 \%$ and reducing 2.863.981,8 $\mathrm{kg}_{\text {of }} \mathrm{CH}_{4}$ emission/years. The evaluation social and economic result show that the technology can be produced biogas equivalent to $5903 \mathrm{~kg}$ of LPG/years, which is able to meet the cooking needs of 40 households. Community perceptions show a positive impact because these activities provide economic benefits around Rp. 35.418.169/years for the community around the tofu industry. Wastewater treatment technology in Proma tofu industry can be integrate the three dimensions of sustainability.
\end{abstract}

Keywords: Tofu, Wastewater, Biogas, Emission, Sustainable, Environment, Social and Economy.

\section{Introduction}

The industry is all forms of economic activity that processes raw materials and/or uses natural resources to produce goods and/or services that have higher economic value and benefits. ${ }^{1}$ Tofu is one of the processed foods from soybeans which is quite potential in Indonesia because the price is cheap and has high nutrition. In general, the tofu industry is included in the types of industries that are classified as small and medium scale, so that its existence can be found together with residential areas. On the other hand, every tofu industry will produce NonProduct Output which can be called waste. Waste generated in the process of making tofu is divided into two, namely wastewater and solid waste. The resulting solid waste is usually sold and used as animal feed, while the wastewater is only disposed of directly into water bodies. Soybean wastewater belongs to high concentration organic wastewater. ${ }^{2}$ Due to its composition (COD: $17.000-26.000 \mathrm{mg} / \mathrm{L}$ ) and the large volumes generated, this represents an environmental problem. ${ }^{3}$ This proves that the value of organic content in tofu wastewater is very high, so special treatment is needed first so that the tofu industry's wastewater does not pollute the environment. 
One of the tofu industries located in the City of Probolinggo named CV. Proma used to dispose of its wastewater directly into the river behind the factory. Proma tofu industry produces wastewater of $5 \mathrm{~m}^{3} /$ day with a capacity of $\pm 700 \mathrm{~kg}$ of soybeans/day. ${ }^{4}$ Based on this statement, it can be calculated that $1 \mathrm{~kg}$ of soybean produces 7.14 liters of wastewater/day or smaller than research Fardiaz states that one kilogram of soybean used in making tofu will produce 8 liters of tofu wastewater. ${ }^{5}$ Disposing of wastewater tofu industry to the environment without any treatment can cause pollution impacts. The odor pollution caused by decay is increasingly felt by the community when the dry season arrives. This has led to protests by residents of tofu industry owners to process their waste before being discharged into the river.

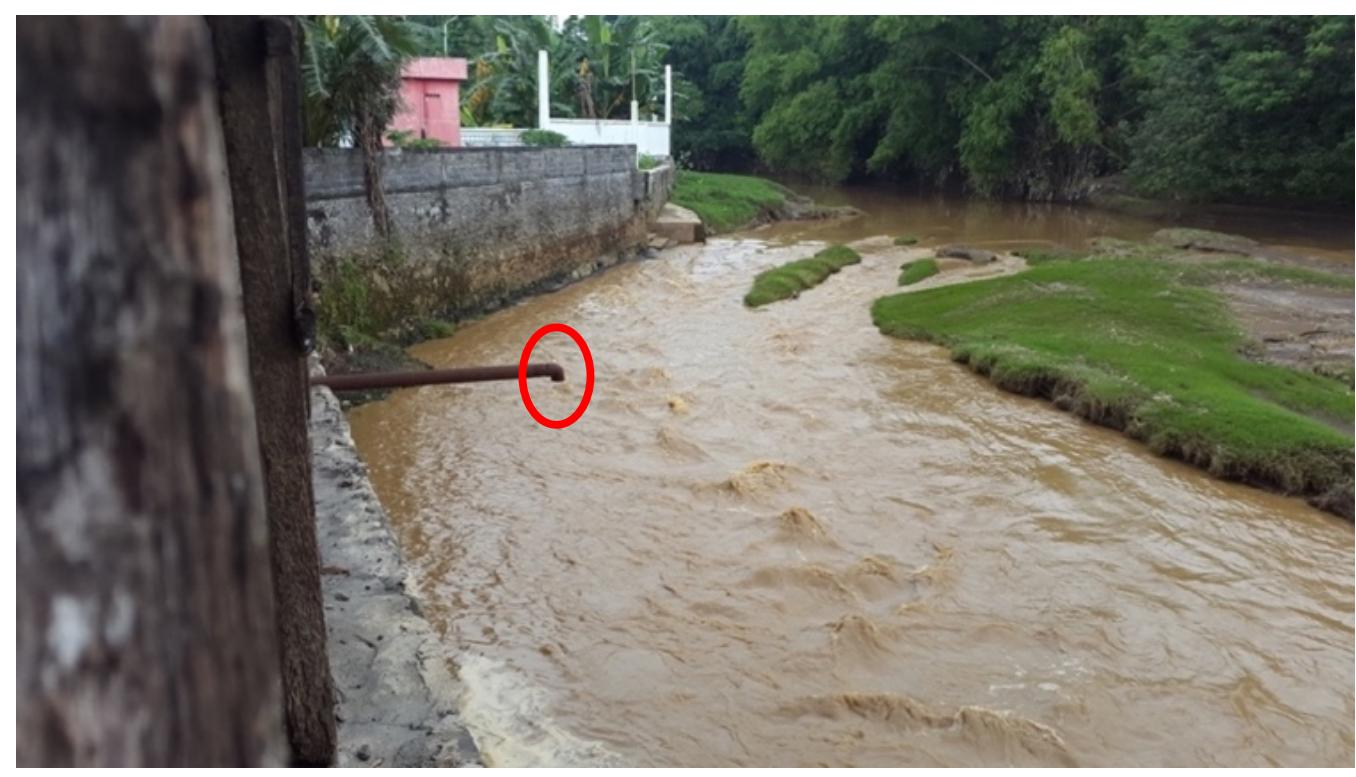

Fig. 1. The tofu wastewater disposal channel in the Proma tofu industry goes directly to the river.

Public protests about the odor pollution caused by decaying organic material in wastewater tofu that has not been utilized make Proma tofu owners at that time trying to process their waste. The wastewater treatment technology CV. Proma is the Fixed Bed type anaerobic reactor. Anaerobic processing technology has two main challenges, namely: (i) operational instability and (ii) the quality of processing produced. ${ }^{6}$ If the process conditions are handled correctly, the anaerobic treatment process will run stable. ${ }^{7}$ The estimated age of this reactor can range from 20 years to 25 years. ${ }^{8,9}$ This latest waste treatment technology runs well until now, where the organic pollutant load on the waste is reduced so that the wastewater does not cause unpleasant odors anymore.

Even though the wastewater tofu industry CV. Proma has been processed, however despite many studies of wastewater treatment, in Indonesia there are not yet studies that have proposed a sustainable approach that can be applied to wastewater treatment facilities that integrate the three dimensions of sustainability (social, economic, and environmental). The aim of the research is to evaluate three impacts (environmental, social, and economic) of sustainability on wastewater treatment at CV. Proma tofu industry. 


\section{Methods}

The research location is in the tofu industry CV. Proma is located on Jalan Raya Kedung Asem 555/A, RT 2/RW 7, Kedung Asem Sub-District, Wonoasih District, Probolinggo City. This research was conducted for 5 months, starting from December 2017 to April 2018. This research generally uses a quantitative approach, while the research method used is a combination of quantitative and qualitative research methods. Quantitative methods are used to analyze the environmental evaluation of the tofu industry waste treatment CV. Proma, while the qualitative method is used to analyze the socio-economic evaluation of the community about the benefits of biogas from tofu industry wastewater treatment. The community is one of the important aspects of seeing the impact of operations because it is the community that is most aware of the impact of environmental changes arising from the effects of industrial activities.

The study population was divided into two, namely 1) wastewater tofu industry and 2) the community. wastewater of the tofu industry consists of two parts, namely wastewater tofu's before treatment and wastewater tofu's after treatment. The second data of this industrial wastewater sample is secondary data obtained based on the combined time method according to SNI 6989.59: 2008. ${ }^{10}$ The combined time method is a method of mixing samples taken at different times with the same volume. The wastewater sample is taken with a polyethylene plastic container and brought to the laboratory to be able to measure the quality of the waste container. Furthermore, an environmental evaluation analysis will be carried out including:

- Formula for the efficiency of the performance wastewater tofu treatment

$$
\% \text { Efficiency COD }=\left(\frac{\text { CODin-CODout }}{\text { CODin }}\right) \times 100 \%
$$

- $\quad$ Formula for the quantity of biogas produced: ${ }^{11}$

Volume $\left(\mathbf{m}^{3}\right)=$ Ps x COD reduced

Volume $\left(\mathrm{m}^{3}\right)=\operatorname{Ps} \times\left\{\mathrm{Q} \times\left(\mathrm{COD}_{\text {in }}-\mathrm{COD}_{\text {out }}\right)\right\}$

Where: $\mathrm{Q}=$ Wastewater debit $\left(\mathrm{m}^{3} /\right.$ day $)$

$\mathrm{Ps}_{\mathrm{S}}=$ the specific gas production $(\mathrm{L} / \mathrm{Kg})$.

Ps is given in Figure 2. Temperature effect on gas production.

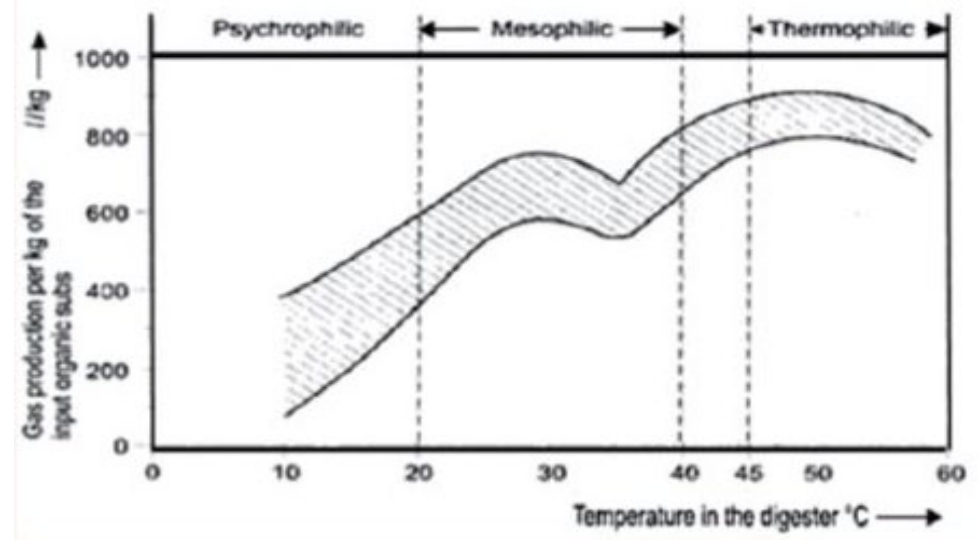

Fig. 2. Temperature effect on gas production ${ }^{12}$

Looking for Ps value by using a graph of the relationship between temperature and gas production at CV. Proma and obtained $\mathrm{Ps}=0,675 \mathrm{~kg} / \mathrm{m}^{3}$, at a temperature of $30^{\circ} \mathrm{C}$. 
- $\quad$ Formula for $\mathrm{CH}_{4}$ Emission: ${ }^{13}$

$\mathrm{CH}_{4}$ emissions $(\mathrm{kg} /$ year $)=\mathrm{COD}(\mathrm{Kg} \mathrm{COD} /$ year $) \times \mathrm{B}_{\mathrm{o}}\left(\mathrm{Kg} \mathrm{CH}_{4} / \mathrm{Kg} \mathrm{COD}\right) \times \mathrm{MCF}$

Where: $\mathrm{COD} \quad=$ is Chemical Oxygen Demand

$\mathrm{B}_{\mathrm{o}} \quad=$ Is maximum methane producing

capacity of certain amount wastewater $\left(0,21 \mathrm{Kg} \mathrm{CH}_{4} / \mathrm{Kg} \mathrm{COD}\right)$

$\mathrm{MCF} \quad=$ Is methane conversion factor

$\left(0,378\right.$ with assumes full anaerobic degradation at $\left.30^{\circ} \mathrm{C}\right)$

Community population is a married woman, who lives around the Proma tofu industry, is approximately 250 meters away, has lived more than 5 years, and uses biogas from tofu industry waste processing. Married women who are assumed to feel more of a direct impact on saving household expenses due to biogas utilization. $1 \mathrm{~m}^{3}$ of biogas is equivalent to $0.46 \mathrm{~kg}$ of LPG. ${ }^{14}$ In Indonesia, the price of $3 \mathrm{~kg}$ LPG in 2019 is Rp. 18.000,-.

Analysis of community socio-economic evaluation through interviews using a questionnaire to the community around the tofu industry. The total population is 40 households, while the determination of the number of samples is done by the Slovin formula with a degree of error of $5 \%$. The Slovin formula is described in equation (4).

$$
n=\frac{N}{1+N e^{2}}
$$

Where:

$\mathrm{N}=$ The Number of Population

$\mathrm{n}=$ The Number of Sample

$\mathrm{e}=$ Fault tolerance limit

Based on these criteria, the total sample of respondents obtained was 36 household. The number of samples will be added 5\% of the total sample to anticipate if there is data that is not good in research, so the total number of samples in this research is 38 household.

\section{Results}

In 2015 , the Proma tofu industry overcame the problem of wastewater by building tofu wastewater treatment using Fixed Bed type anaerobic reactor technology with a buffer material useful as a place to attach bacteria. The total capacity of anaerobic reactors built for processing industrial wastewater tofu is $43 \mathrm{~m}^{3}$ and the capacity of the gasholder is $27 \mathrm{~m}^{3}$. Anaerobic wastewater treatment can help reduce of pollutants load from organic wastewater in the environment and can produce biogas. Biogas will be channeled into a temporary gas reservoir or gas holder before distribution to residents' homes. Processing wastewater tofu industry CV. Proma, Probolinggo can be seen in Figure 3. 


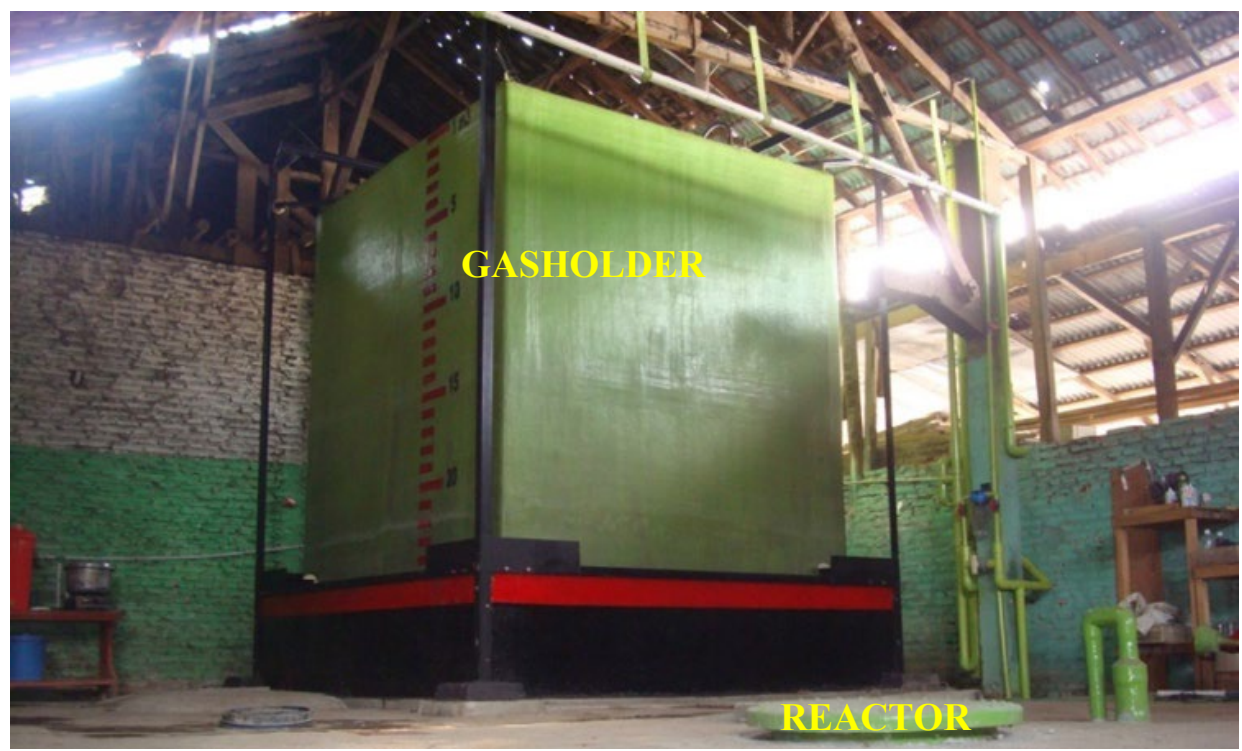

Fig. 3. Tofu industrial wastewater treatment CV. Proma

In this study an evaluation of the Proma tofu industry wastewater treatment with three dimensions of sustainability (social, economic, and environmental sustainability) can be explained as follows:

\section{A. Environmental impact}

Environmental impacts are felt after the wastewater treatment CV. Proma reduces the organic content of wastewater which can be seen in Table 1.

Table 1. Decreased organic wastewater content of the Proma tofu industry

\begin{tabular}{cccccc}
\hline No & Date & COD In (mg/L) & COD Out (mg/L) & Load (mg/L) & Eff (\%) \\
\hline 1 & 19 March 2015 & 7743,40 & 1545,65 & 6197,75 & 80 \\
2 & 24 March 2015 & 7458,80 & 1491,10 & 5967,70 & 80 \\
3 & 28 July 2015 & 7212,20 & 714,10 & 6498,10 & 90 \\
4 & 29 Augs 2017 & 7849,13 & 1647,33 & 6201,80 & 79 \\
5 & 30 Augs 2017 & 4397,91 & 1193,86 & 3204,05 & 73 \\
6 & 26 Sept 2017 & 7960,71 & 1842,64 & 6118,07 & 77 \\
7 & 27 Sept 2017 & 7426,37 & 1836,4 & 5589,97 & 75 \\
& Averages & 7149,79 & 1467,30 & 5682,50 & 79 \\
\hline
\end{tabular}

Based on the data in Table 1, it can be seen the performance of the Fixed Bed CV. Proma can be described as follows:

- In 2015 the average COD (in) content of tofu wastewater before it was processed was $7471,47 \mathrm{mg} / \mathrm{l}$, while the average COD content (out) of tofu wastewater that came out of the waste treatment reactor was $1250,22 \mathrm{mg} / \mathrm{l}$. The average efficiency of the tofu wastewater treatment was $83 \%$ with an average COD load is $6221,18 \mathrm{mg} / \mathrm{l}$ and the reactor was operated according to the actual tofu wastewater condition at temperatures around $30^{\circ} \mathrm{C}$.

- In 2017, the average COD content of tofu wastewater before processing (in) was 
$6908,53 \mathrm{mg} / \mathrm{l}$, while the average COD content of tofu wastewater after processing (out) was $1630,05 \mathrm{mg} / \mathrm{l}$. The average efficiency of COD of tofu wastewater treatment is $75 \%$ with an average COD load of $5278,48 \mathrm{mg} / 1$ and temperature around $30^{\circ} \mathrm{C}$.

\section{B. Social and Economy Impact.}

The social and economic impact is obtained from the results of the questionnaire which is divided into 3 categories and explained as follows:

1) Characteristics of Respondent

Characteristics of respondent divided into four (4) questions are ages, education, job, and long stay.

Table 2. Characteristics of Respondent

\begin{tabular}{|c|c|c|c|}
\hline No & Indicator & Respondents & $(\%)$ \\
\hline \multirow[t]{7}{*}{1} & Age & & \\
\hline & $8-28$ years & 4 & $11 \%$ \\
\hline & $29-39$ years & 10 & $28 \%$ \\
\hline & $40-50$ years & 14 & $39 \%$ \\
\hline & 51-61 years & 2 & $6 \%$ \\
\hline & $62-100$ years & 6 & $17 \%$ \\
\hline & Total & 36 & $100 \%$ \\
\hline \multirow[t]{6}{*}{2} & Education & & \\
\hline & SD & 23 & $64 \%$ \\
\hline & SMA & 4 & $11 \%$ \\
\hline & SMP & 5 & $14 \%$ \\
\hline & S1 & 4 & $11 \%$ \\
\hline & Total & 36 & $100 \%$ \\
\hline \multirow[t]{8}{*}{3} & Jobs & & \\
\hline & Employee at CV Promatun Sarroyan & 4 & $11 \%$ \\
\hline & Farmers & 2 & $6 \%$ \\
\hline & Labors & 6 & $17 \%$ \\
\hline & Traders & 6 & $17 \%$ \\
\hline & Housewifes & 16 & $44 \%$ \\
\hline & Teachers & 2 & $6 \%$ \\
\hline & Total & 36 & $100 \%$ \\
\hline \multirow[t]{7}{*}{4} & Long stays & & \\
\hline & $0-5$ years & - & - \\
\hline & $5-15$ years & 3 & $8 \%$ \\
\hline & $16-30$ years & 9 & $25 \%$ \\
\hline & $31-45$ years & 6 & $17 \%$ \\
\hline & $>45$ years & 18 & $50 \%$ \\
\hline & Total & 36 & $100 \%$ \\
\hline
\end{tabular}

2) Community Knowledge

Community knowledge divided into five (5) questions are wastewater from tofu industry, complaints, wastewater treatment, benefit of wastewater treatment, wastewater impact to environtment. 
Table 3. Community Knowledge

\begin{tabular}{|c|c|c|c|c|}
\hline No & Indicator & & Respondents & $(\%)$ \\
\hline \multirow[t]{9}{*}{1} & Wastewater from tofu industry & & & \\
\hline & Wastewater & & 11 & $31 \%$ \\
\hline & Solid waste & & - & - \\
\hline & Air waste & & - & - \\
\hline & Air waste and Wastewater & & 17 & $47 \%$ \\
\hline & Wastewater and Solid waste & & - & - \\
\hline & Solid waste and Air waste & & - & - \\
\hline & Solid waste, Wastewater, and Air wast & & 8 & $22 \%$ \\
\hline & & Total & 36 & $100 \%$ \\
\hline \multirow[t]{4}{*}{2} & Complaints & & & \\
\hline & Yes & & 1 & $3 \%$ \\
\hline & No & & 35 & $97 \%$ \\
\hline & & Total & 36 & $100 \%$ \\
\hline \multirow[t]{4}{*}{3} & Wastewater treatment & & & \\
\hline & Important & & 36 & $100 \%$ \\
\hline & Not important & & - & - \\
\hline & & Total & 36 & $100 \%$ \\
\hline \multirow[t]{6}{*}{4} & Benefit of wastewater treatment & & & \\
\hline & Nothing & & - & - \\
\hline & Clean environment & & 2 & $6 \%$ \\
\hline & Biogas & & 12 & $33 \%$ \\
\hline & Biogas and clean environment & & 22 & $61 \%$ \\
\hline & & Total & 36 & $100 \%$ \\
\hline \multirow[t]{5}{*}{5} & Wastewater impact to environtment & & & \\
\hline & Not damage & & 20 & $56 \%$ \\
\hline & damage & & 4 & $11 \%$ \\
\hline & Damage and incure losses & & 12 & $33 \%$ \\
\hline & & Total & 36 & $100 \%$ \\
\hline
\end{tabular}

\section{3) Utilization of Biogas}

Utilization of biogas divided into ten (10) questions are long time using biogas, utilization of biogas, people in one house, fuel for cooking before using biogas, fuel before using biogas, after using biogas, cooking stove, how long time for cooking, reasons for using biogas, reasons for using biogas, and barriers while using biogas.

Table 4. Utilization of Biogas

\begin{tabular}{|c|c|c|c|c|}
\hline No & Indicator & & Respondents & $(\%)$ \\
\hline \multirow[t]{5}{*}{1} & Long time using biogas & & & \\
\hline & $<1$ year & & 1 & $3 \%$ \\
\hline & $1-2$ years & & 13 & $36 \%$ \\
\hline & $3-4$ years & & 22 & $61 \%$ \\
\hline & & Total & 36 & $100 \%$ \\
\hline \multirow[t]{4}{*}{2} & Utilization of biogas & & & \\
\hline & Cooking food for family & & 33 & $92 \%$ \\
\hline & Cooking food for sale & & 3 & $8 \%$ \\
\hline & & Total & 36 & $100 \%$ \\
\hline \multirow[t]{2}{*}{3} & People in one house & & & \\
\hline & $1-2$ people & & 5 & $14 \%$ \\
\hline
\end{tabular}




\begin{tabular}{|c|c|c|c|c|}
\hline No & Indicator & & Respondents & $(\%)$ \\
\hline & 3-4 people & & 16 & $44 \%$ \\
\hline & 5-6 people & & 14 & $39 \%$ \\
\hline & 7-8 people & & 1 & $3 \%$ \\
\hline & & Total & 36 & $100 \%$ \\
\hline \multirow[t]{5}{*}{4} & Fuel for cooking before using biogas & & & \\
\hline & LPG & & 29 & $81 \%$ \\
\hline & Firewood & & 5 & $14 \%$ \\
\hline & LPG and Firewood & & 2 & $6 \%$ \\
\hline & & Total & 36 & $100 \%$ \\
\hline \multirow[t]{7}{*}{5} & Fuel before using biogas & & & \\
\hline & 1 tube $\mathrm{LPG} 3 \mathrm{~kg}$ & & 6 & $19 \%$ \\
\hline & 2 tube $\mathrm{LPG} 3 \mathrm{~kg}$ & & 10 & $32 \%$ \\
\hline & 3 tube $\mathrm{LPG} 3 \mathrm{~kg}$ & & 9 & $29 \%$ \\
\hline & 4 tube LPG $3 \mathrm{~kg}$ & & 5 & $16 \%$ \\
\hline & 8 tube $\mathrm{LPG} 3 \mathrm{~kg}$ & & 1 & $3 \%$ \\
\hline & & Total & 31 & $100 \%$ \\
\hline \multirow[t]{4}{*}{6} & After using biogas & & & \\
\hline & 0 tube $\mathrm{LPG} 3 \mathrm{~kg}$ & & 36 & $100 \%$ \\
\hline & 1 tube $\mathrm{LPG} 3 \mathrm{~kg}$ & & - & - \\
\hline & & Total & 36 & $100 \%$ \\
\hline \multirow[t]{6}{*}{7} & Cooking stove & & & \\
\hline & 1 & & 3 & $8 \%$ \\
\hline & 2 & & 31 & $86 \%$ \\
\hline & 3 & & - & - \\
\hline & 4 & & 2 & $6 \%$ \\
\hline & & Total & 36 & $100 \%$ \\
\hline \multirow[t]{5}{*}{8} & How long time for cooking & & & \\
\hline & $1-2$ hour/day & & 28 & $78 \%$ \\
\hline & 3-4 hour/day & & 7 & $19 \%$ \\
\hline & 5-6 hour/day & & 1 & $3 \%$ \\
\hline & & Total & 36 & $100 \%$ \\
\hline \multirow[t]{5}{*}{9} & Reasons for using biogas & & & \\
\hline & Saving & & 2 & $6 \%$ \\
\hline & Safe and saving & & 9 & $25 \%$ \\
\hline & Safe, saving, and environmental friendly & & 25 & $69 \%$ \\
\hline & & Total & 36 & $100 \%$ \\
\hline \multirow[t]{4}{*}{10} & Barriers while using biogas & & & \\
\hline & Nothing & & 19 & $53 \%$ \\
\hline & Biogas cannot be used on certain days & & 17 & $47 \%$ \\
\hline & & Total & 36 & $100 \%$ \\
\hline
\end{tabular}

\section{Discussion}

\section{A. Environmental impact Analysis}

The efficiency of COD in 2017 decreased when compared to 2015, this could be due to changes in the volume of wastewater filling entering the reactor and the excessive use of water resulting in dilution. The decline in wastewater production is also caused by the existence of trade competition between fellow tofu industries to make the tofu production $\mathrm{CV}$. Proma decreases, and the waste it produces also decreases. At present, the Proma tofu factory only 
produces $630 \mathrm{~kg}$ of soybeans per day, while in 2015 the Proma tofu factory can process around $700 \mathrm{~kg}$ per day.

If calculated the average efficiency of the performance of the wastewater treatment industry CV. Proma as a whole is $79 \%$. This is consistent with the theory of Metcalf and Eddy which states that the efficiency of the fixed bed type reactor performance can reach $75-85 \%{ }^{15}$

The composition of the organic content of the degraded tofu industry wastewater greatly influences the amount of biogas formed. Organic substrates play an important role in the stability of anaerobic treatment systems because some raw materials can have an inhibitory effect on the anaerobic treatment process. ${ }^{16}$ The best conditions were obtained when filling the wastewater in a fixed bed reactor at a maximum of 7.700 liter/day with a COD load of 6221,18 $\mathrm{mg} / \mathrm{L}$, producing biogas of $35.158 \mathrm{Liter} /$ day with an average methane gas content of $66 \%$. This shows that organic fatty acids formed in the anaerobic treatment system can be put to good use by methane-forming bacteria at a maximum of $66 \%$. Based on the theory of Boursier ${ }^{11}$ theoretical biogas production can be calculated through the multiplication between the reduction in COD load $\left(\mathrm{kg} \mathrm{COD} /\right.$ hari) with the specific gas production factor $\left(\mathrm{kg} / \mathrm{m}^{3}\right)$. The theoretical biogas production Bousier ${ }^{11}$ obtained in the condition of waste filling was 7700 liters, the average COD load was $6221.18 \mathrm{mg} / 1$ and the temperature of $30^{\circ} \mathrm{C}$ was 32,334 liters per day, whereas in actual conditions the maximum biogas production produced was 35,158 liters per day. This shows that the biogas production produced is greater than the biogas production theoretically calculated. This can be made possible because anaerobic bacteria can process the solids contained in the wastewater of tofu such as pieces of crushed tofu, soybean shells, etc., which are accidentally included in the reactor and break down into biogas.

Decreasing the organic content of wastewater from the Proma industry also produces another advantage, namely reducing greenhouse gas emissions. If calculated using the AM0013, CDM-UNFCCC/CCNUCC method $^{13}$, then from the 7700 liters of Proma tofu industry wastewater treatment using anaerobic fixed bed reactor can reduce air pollution emissions by $2,863,981.8 \mathrm{~kg} \mathrm{CH} 4 /$ year. With the application of this technology in every tofu industry in Indonesia, it is expected to become one of the sectors that can support the Action Plan for Reduction of Greenhouse Gas Emissions specifically for industry and help support environmental sustainability providing benefits to the community.

\section{B. Social and Economy Impact Analysis}

The social and economic impact is obtained from the results of the questionnaire which is divided into 3 categories and explained as follows:

1) Characteristics of Respondent

The survey results show that the majority of respondents are in the age range of 40-50 years which is equal to $39 \%$, and the minority of respondents are in the age range of 5161 years which is equal to $5 \%$. This condition certainly has a picture that all respondents have reached the ideal age for a person or individual to be more mature and mature in terms of the views and insights of the surrounding environment. Education is one indicator that is considered to be able to determine the mindset of respondents regarding good environmental management. The survey results show that the majority of respondents have an elementary education background, and the rest only a small proportion of respondents have junior high, high school, and undergraduate education. The main livelihood of the majority of respondents is housewives. The average respondent has lived long enough to stay in that location, so it is assumed that the 
respondent is familiar with the changes in the environment that occur around him.

2) Community Knowledge

Questionnaire data on community knowledge is used to describe the extent to which community knowledge of the waste produced by the tofu industry, the impacts that occur in the environment, and public concern for the environment. Descriptive description of the respondent's knowledge can be explained as follows:

- The survey results state that the community knows that the tofu industry produces wastewater because they feel the direct benefit of processing tofu wastewater into biogas, but the majority of the community is also not aware of any solid waste produced by the tofu industry, because they consider that solid waste from tofu industry still has economic value to be sold as animal feed.

- Based on the results of a questionnaire about the respondents' knowledge of the discharge of wastewater into the environment, it was found that as many as $56 \%$ answered it was not dangerous. This happens because in the past the wastewater produced by the Proma tofu industry was directly discharged into the big river Kedungasem and directly carried by the water flow to the estuary.

- Based on questions about community protests against the waste produced by the tofu industry, the majority of respondents answered that they had never protested, and only 1 family had stated that he had once protested against the owner of the Proma tofu industry. Other reluctance of the community towards tofu industry owners is the main reason for the majority of residents who have never protested against the waste dumped in the environment. Palmerg and Kuru show that motivation to act for environmental problems can be stimulated by increasing awareness and knowledge about environmental action strategies. ${ }^{17}$ In reality, the nature of sympathy for the environment is not always directly proportional to high education. This can be seen in one of the questionnaires which stated that only one respondent dared to express his protest to the owner of the Proma tofu industry and that the respondent had only an elementary school education. The respondent claimed to protest because he felt the environment around his residence was polluted due to the smell of rotting liquid. His concern paid off because tofu industry owners tried to treat their liquid waste before it was discharged into the environment. This is consistent with the research of Erdogan and Ozsoy which states that there is no relationship between education and environmental awareness. ${ }^{18}$

- Based on questionnaire questions to the public about how important tofu wastewater must be treated, a yield of $100 \%$ of respondents considers that wastewater treatment is important to be treated, because it benefits the economy of the community.

- Based on the questionnaire distributed to the public about the benefits of tofu industry waste treatment, it was found that the majority of residents by $61 \%$ answered that tofu industry wastewater treatment produced biogas benefits and the environment became clear. Most of the residents consider that the Proma tofu industry now does not directly dispose of its waste into the river so that the river water becomes cleaner than before.

3) Utilization of Biogas

Questionnaire data regarding the use of biogas is used to calculate a simple evaluation of the use of biogas. Descriptive description of the use of biogas can be explained as follows: 
- The average community has felt the use of biogas for 2-3 years. The majority of people use biogas to cook their daily needs, while the rest use biogas to cook food that can be sold, such as fried food, steam food, etc. The direct impact on the use of biogas is felt by the community because it can save LPG purchases for cooking needs.

- Characteristics of respondents based on the number of people in one house will affect the length and number of biogas used. The more inhabitants, it is directly proportional to the length of cooking activities so that more biogas is used. Likewise, the increasing number of furnaces and the length of cooking time are the main factors affecting the amount of biogas used.

- In the past, the majority of people used LPG fuel for cooking needs, and on average a month could take 2-3 LPG tubes of $3 \mathrm{~kg}$. After the existence of biogas, most people no longer use LPG because the biogas already meets the needs of the community. Based on several comments from the community, it is stated that they still have $3 \mathrm{~kg}$ LPG gas cylinders which are used as a backup if at any time the tofu industry CV. Proma is not operating or is on holiday.

- $\quad$ From an economic side, with the use of biogas, the community gets monthly cost savings. If it is assumed biogas produced by wastewater treatment tofu industry CV. Proma is 35.158 Liters/day or equivalent to 12.832 .670 liters of biogas/year, then the equivalent of $5903 \mathrm{~kg}$ of LPG per year, and economic savings of the community with the use of biogas is Rp. 35.418.169 per year.

- The majority of people stated that the reasons for using biogas include safe, saving and environmentally friendly. The safe use of biogas is because the largest component in biogas is containing methane gas, where methane gas has a pressure low so that it is not easy to explode. Biogas is a neutral energy source of carbon dioxide $\left(\mathrm{CO}_{2}\right)$. Biogas has pressure under ambient air, while the maximum biogas pressure can reach 10 mbar above atmospheric pressure. ${ }^{19}$

Barriers while using biogas, the majority of respondents answered biogas can not be used on certain days because it coincides with the holiday, which is accompanied by the cessation of the process of making tofu so that no liquid waste is produced and the biogas does not produce. Nevertheless, the community claimed to be happy with the provision of biogas as a sign of compensation from the owner of the tofu industry to the community. In addition to biogas for daily cooking needs, the community also received other compensation in the form of distribution of holiday gifts to the community, as well as the existence of cooperatives for the welfare of the community around the Proma tofu industry. This shows that public perceptions of the Proma tofu industry have a positive impact and interrelationship with the principle of usefulness so that there arises greater community tolerance for not protesting about the environmental conditions of the tofu industry. Protecting nature and the environment and maintaining it for future generations are the main things that must be considered by every community, not only based on the value of benefits but also aware of the commitment and responsibility towards the environment. 


\section{Conclusion}

Wastewater treatment technology in Proma tofu industry can reduce organic materials and $\mathrm{CH}_{4}$ emissions from the environmental side, provide economic benefits from the economic side, and community support from the social side. It shows Wastewater treatment technology in Proma tofu that it can integrate the three dimensions of sustainability (social, economic, and environmental).

\section{Declaration of Interest}

The authors report no declarations of interest. The authors alone are responsible for the content and writing of the paper.

\section{References}

[1] Rizal, Reda. (2013). Manajemen Ekologi Industri. Penerbit Universitas Indonesia (UI-Press), 2013.ISBN:978-979-456-533-9.

[2] Serventi, Luca. Wang, Yifei., (2019). Sustainability of dairy and soy processing: A review on wastewater recycling. Journal of Cleaner Production. JCLP 117821. S0959-6526(19)32681-2.

[3] Belen, F., Sanchez, J., Hernandez, E., Auleda, J.M., Revantos, M. (2012). One option for the management of wastewater from tofu production: Freeze concentration in a falling-film system. Journal of Food Engineering 110 (2012) 364-373.

[4] Germadi, Arif., Marbun, Trifena Karunia. (2017). Studi Pengelolaan limbah cair pabrik tahu di Dinas Lingkungan Hidup (DLH) Kota Probolinggo. Institut Teknologi Sepuluh Nopember. Department of Environmental Engineering. Faculty of Civil, Environmental and Earth Engineering. Surabaya.

[5] Fardiaz, D. (1988). Utilization of Waste Product from Tofu and Tempe Processing. Proceeding Workshop on Tofu and Tempe Processing. Bogor Agricultular. University Research Inctitute, Bogor: 162-165

[6] Appels, L., Lauwers, J., Degrève, J., Helsen, L., Lievens, B., Willems, K., Van Impe, J., Dewil, R., (2011). Anaerobic digestion in global bio-energy production: potential and research challenges. Renew. Sustain. Energy Rev. 15 (9), 4295-4301.

[7] Dechrugsa, S., Kantachote, D., Chaiprapat, S., (2013). Effects of inoculum to substrate ratio, substrate mix ratio and inoculum source on batch co-digestion of grass and pig manure. Bioresour. Technol. 146, 101-108.

[8] Yao, Jingang., Kraussler, Michael., Benedikt, Florian., Hofbauer, Hermann. (2017). Technoeconomic assessment of hydrogen production based on dual fluidized bed biomass steam gasification, biogas steam reforming, and alkaline water electrolysis processes. Energy Conversion and Management 145 (2017) 278-292.

[9] Raheem, Abdur., Hassan, Mohammad Yusri., Shakoor, Rabia. (2016). Bioenergy from anaerobic digestion in Pakistan: Potential, development and prospects. Renewable and Sustainable Energy Reviews 59 (2016) 264-275.

[10] Badan Standarisasi Nasional (BSN). (2008). Air dan air limbah: Metoda pengambilan contoh air limbah. Jakarta. Metode Standarisasi Nasional Indonesia SNI 6989.59:2008.

[11] Boursier, H. (2003). Etude et modélisation des processus biologiques aux cours du traitement aérobie $d u$ lisier en vue d'une optimisation $d u$ procédé, Thèse Ingénieur Génie de l'Environnement, Ecole des Mines de Nantes, 203p. 
[12] Nijaguna, B.T. (2002). Biogaz Technologies, New Age Internacional publishers, 298p. Principal, I S S Academy Of Technical Education, Bangalore, Karnataka, India

[13] IPCC (2006): Guidelines for National Greenhouse Gas Inventories. Intergovernmental Panel on Climate Change

[14] Wahyuni, Sri. (2009). Biogas. Jakarta: Penebar Swadaya

[15] Metcalf., Eddy. (2003). Wastewater Engineering Treatment and Reuse. The McGraw Hill Companies, Inc. EISBN 0-07-112250-8

[16] Fagbohungbe, Michael O., Herbert, Ben M.J., Hurst, Lois., Ibeto, Cynthia N., Li, Hong., Usmani, Shams Q., Semple, Kirk T. (2017). The challenges of anaerobic digestion and the role of biochar in optimizing anaerobic digestion. Waste Management 61 (2017) 236-249.

[17] Palmerg, I.E., \& Kuru, J. (2000). Outdoor Activities as a Basis for Environmental Responsibility. Journal of Environmental Education, 31 (4), 32-37.

[18] Erdogan, M., Ozsoy, A. M. (2007). Graduate Students Perspectives on The Human-Environment Relationship. R. Assist., Middle East Technical University, Faculty of Education, Dept. of Educational Sciences, Ankara. Journal of Turkish Science Education. Volume 4, Issue 2, September 2007

[19] Lemmer, Andreas., Merkle, Wolfgang., Baer, Karina., Graf, Frank. (2017). Effects of highpressure anaerobic digestion up to 30bar on $\mathrm{pH}$-value, production kinetics and specific methane yield. Energy 138 (2017) 659-667. Science Direct. Elsevier. 